\title{
Impact of Urban Expansion on Forest Carbon Sequestration: a Study in Northeastern China
}

\author{
Wei Zhang ${ }^{1}$, Jun $\mathrm{Ma}^{3}$, Miao Liü ${ }^{2 *}$, Chunlin $\mathrm{Li}^{2}$ \\ ${ }^{1}$ College of Soil and Environment, Shenyang Agricultural University, Shenyang, China \\ ${ }^{2}$ CAS Key Laboratory of Forest Ecology and Management, Institute of Applied Ecology, \\ Chinese Academy of Sciences, Shenyang, China \\ ${ }^{3}$ Institute of Biodiversity Science, Fudan University, Shanghai, China
}

Received: 14 August 2018

Accepted: 27 December 2018

\begin{abstract}
Urban expansion is one of the features of urban development that has caused many ecological and environmental problems. Evaluating the impact of urban expansion on carbon sequestration of the urban forest is important to understand the carbon cycle in urban ecosystems. Multiple remote sensing data were used to map land covers and carbon sequestration indicators of Shenyang in 2000, 2005, and 2010. Urban land area percentage (UAP), urban expansion magnitude (UEM), net primary productivity (NPP), aboveground biomass (AGB), and the change rate of NPP (RNPP) and AGB (RAGB) were analyzed in regions with different distances from the urban core. Results showed that the decline of UAP and bimodal fluctuation of UEM was found as the increase of distance from urban center. Urban forest NPP and AGB both rose with distance from urban center increased. Significant differences in NPP and AGB existed in various urban forest types. Moreover, UAP was significantly negatively correlated with NPP and AGB. We conclude that urban forests see more disturbances compared to natural forests. The evergreen coniferous forest has the highest ability of carbon sequestration, and great potential of carbon storage is found in the urban forest. Besides, the urban forest's carbon sequestration function will be maintained when adopting appropriate urban development mode.
\end{abstract}

Keywords: Land use change, Landsat TM, MODIS, urban forest, forest carbon sequestration

\section{Introduction}

Land use change is an important aspect of global change, and it drives the developments and changes of regional environment [1] that has aroused much attentions recently. Many ecological problems such as biodiversity loss, reduction of forest productivity,

*e-mail: lium@iae.ac.cn soil erosion, and water pollution have emerged due to unreasonable land use change [2]. Land use decisions are influenced by natural resource conditions and socioeconomic factors [3]. Consequently, sustainable land use policy has significance in maintaining the original functions of terrestrial ecosystems.

As an artificial ecosystem, urban areas cover only $1-2 \%$ of global land, but count for about half of the global population [4]. Sharp growth of population and rapid urbanization make the city expand to a large extent and size, especially in recent decades [5-7]. Urban expansion 
is one of the features of urban development, and it will transform other land types to urban land. Restricted by environment conditions, urban expansion magnitude (UEM) and urban land area percentage (UAP) show various spatial distribution patterns, and they are indexes of reflecting urban expansion $[8,9]$. Commonly, as the distance from the urban core increases, a large area of land is converted into urban land, it will cause UEM to present an increasing trend. In a period of urban construction, ecological problems emerge when environmental conditions change abnormally [10].

Nature ecosystems around cities, especially urban forests, have been impacted by the processes of urban expansion. Besides carbon sequestration [11], urban forest plays a vital role in cleaning air [12, 13], oxygen release [14], and aesthetic appreciation [15] in urban areas. Good protections are usually carried out in urban forests; however, the circumstance around them are not conducive to growth. Natural and anthropogenic disturbances may shift carbon stock in urban forests into the atmosphere [6]. Studies indicate both positive and negative effects on carbon sequestration of urban forests under urbanization [16, 17]. Therefore, great significance lies in exploring the relationship between the urban expansion process and urban forest carbon sequestration.

Net primary productivity (NPP) and aboveground biomass (AGB) are two important indexes in reflecting carbon sequestration of forests. NPP is the amount the remainder of chemical energy, converted from solar energy by vegetation photosynthesis, subtract the consumed part by respiration [18]. Forest AGB reflects the state of accumulation of chemical energy. They are both indicators of the function that forests play in global carbon cycle under global change. Losses of NPP may alter atmosphere composition [19], availability of water [20], and the supply and distribution of energy [21], while decline of forest AGB will increase the emission of greenhouse gas [22]. Factors including land use change and climate change can cause alteration of NPP and AGB, and many studies have focused on urban expansion and its impact on urban forest carbon sequestration $[4,17]$.

Accurate estimation of NPP and AGB is essential for exploring the dynamics of urban forest carbon sequestration [11]. A lot of methods such as field sampling and remote sensing inversion are applied in evaluating forest NPP and AGB. Forest inventory and field observation methods usually estimate NPP and AGB with higher accuracy. However, these methods need huge financial supports and a lot of time, and they cannot provide results of spatial surface. Remote sensing images not only give the spatial surface AGB data, but are also easy and freely obtained. Multiple remote sensing data, including radar data, can improve the accuracy of the estimation of forest AGB [23]. The Carnegie Ames Stanford application (CASA) productivity model is widely used in NPP evaluation. Based on meteorological and remote sensing normalized difference vegetation index (NDVI) data, the CASA model can evaluate a forest ecosystem's NPP [24].

Forest type is another significant variable influencing the carbon sequestration of urban forests. Unlike nature forests, an urban forest receives more human management. Urban forest types are relatively stable and do not change with time. Variances of the carbon sequestration ability exist in different forest types [25]. Therefore, the distribution of urban forest types may have the potential to influence spatial patterns of carbon sequestration.

Many studies have researched the relationship between urban expansion and carbon sequestration of urban forests [11, 26, 27]. However, most of them are focused on urban forest carbon storage in different regions of a city. Few attentions have been paid on the dynamics of urban forest carbon sequestration with various gradients of urban expansion indexes. The objectives of this study were to: (1) quantify urban expansion of different distance from the urban center in Shenyang city, (2) explore the dynamics of urban forest NPP and AGB of different distance from urban center and different forest types, and (3) explore the relationship between urban expansion gradients and urban forest carbon sequestration.

\section{Materials and Methods}

\section{Study Area}

Shenyang $\quad\left(41^{\circ} 11^{\prime} 51^{\prime \prime}-43^{\circ} 02^{\prime} 13^{\prime \prime} \mathrm{N}, \quad 122^{\circ} 25^{\prime} 09^{\prime \prime}-\right.$ $123^{\circ} 48^{\prime} 24^{\prime \prime} \mathrm{E}$ ), lies in the transition zone between a branch of the Changbai Mountains and the flood plain of the Liao River, which is the capital of Liaoning Province and the communications, commercial, scientific, and cultural center of northeastern China (Fig. 1). It covers
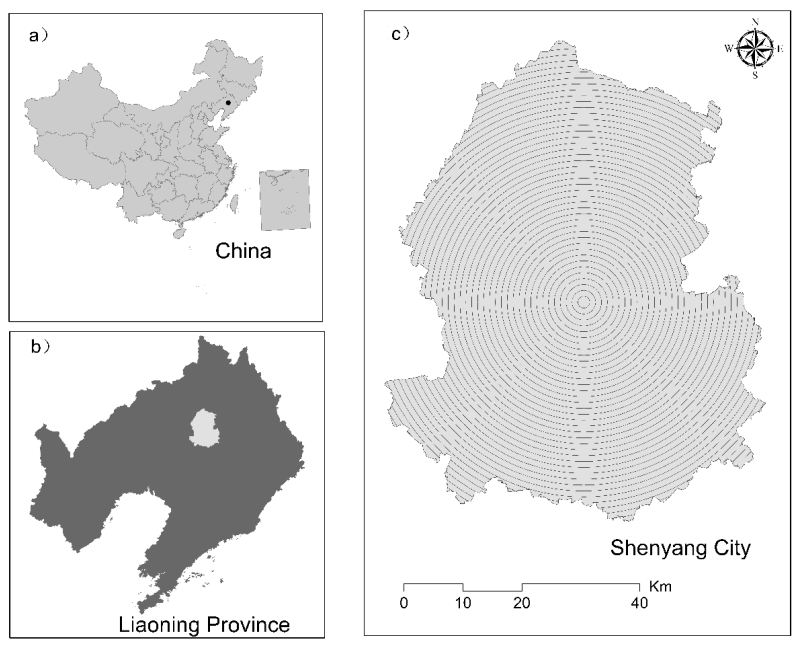

Fig. 1. Location of Shenyang city in northeastern China: a) Liaoning Province; b) Shenyang in Liaoning; and c) the different buffer rings of the Shenyang urban area; the width of each buffer ring is $1 \mathrm{~km}$. 
about $3495.4 \mathrm{~km}^{2}$. The major topography is characterized by an alluvial plain in the west, with low hilly lands in the northeast and southeast. Shenyang is located in the temperate sub-humid continental climate zone. It experiences cold winters (mean January temperature, $-17.6^{\circ} \mathrm{C}$ ) and warm summers (mean July temperature, $26^{\circ} \mathrm{C}$ ), while the average annual air temperature is $8.3^{\circ} \mathrm{C}$. The mean annual precipitation falls mostly from June to August, and sunshine hours are $670.9 \mathrm{~mm}$ and $2596.3 \mathrm{~h}$, respectively. The dominant urban forest types of Shenyang are deciduous broad-leaved forests, deciduous conifer forests, evergreen conifer forests, and garden forests. There is almost no shrub land is this area; the shrub was already considered in urban forests.

As a key investment and industrial base designed by the Chinese government since 1948, Shenyang developed into the center of Chinese heavy industrial development before the $1980 \mathrm{~s}$, and it entered into a new period of development at the end of the last century. Shenyang is regarded as the core city of central Liaoning urban agglomeration, one of ten urban agglomerations in China, from the beginning of this century and has experienced rapid urban development. The GDP of Shenyang in 2000, 2005, and 2010 was 93.79 billion, 181.73 billion, and 418.49 billion RMB yuan, respectively. With the growth of its population, the urban land of Shenyang expanded at a high speed.

\section{Data Collection}

Remote sensing data, meteorological data, and ground observation data were all applied in this study. Landsat thematic mapper (TM) images with $30 \mathrm{~m}$ solution for 2000, 2005, and 2010, downloaded from United States Geological Survey (USGS), were used to map Shenyang land cover from those times. MODIS NDVI products, including red band and infrared band for 2000,2005 , and 2010 were also used. The temporal and spatial resolutions of these NDVI products are 16-day and $250 \mathrm{~m}$, respectively. Using MODIS-based NDVI, we calculated NPP in the CASA model. The MODIS-based NDVI products were downloaded from the EROS Data Center Distributed Active Archive Center (EDC DAAC) and reproduced at $30 \mathrm{~m}$ spatial resolution to match the land cover data by bilinear interpolation resampling method. Release-31 of the geoscience laser altimeter system (GLAS) data was acquired from the National Snow and Ice Data Center (NSIDC) Web site and used for estimating urban forest AGB.

Three cloudless Landsat TM images in growing season were selected to interpreter Shenyang land cover in 2000, 2005, and 2010. These images were all taken in July. Image registrations such as atmospheric correction, ortho-rectification, and geometry correction were conducted. Edge sharpening enhancement processing was conducted with TM images, and the root mean square (RMS) is less than one pixel. Exact locations of ground control points (GCPs) were obtained using global positioning system (GPS) instruments, and different land covers and their features were surveyed at these locations. We masked the TM image by the Shenyang administrative geographical boundaries. 188 evenly distributed GCPs were investigated to rectify the geometric accuracy of each TM image. We chose the decision tree analysis approach to map the land cover using the maximum likelihood method. The artificial tree-building method was chosen to divide land cover types with clear spectrum mechanisms, while most neighboring methods were applied in those types with high variation spectrum. The final land cover maps for 2000, 2005, and 2010 were classified into six types: urban, forest, water body, cropland, grassland, and bare land. We conducted field investigations to verify and modify the land cover

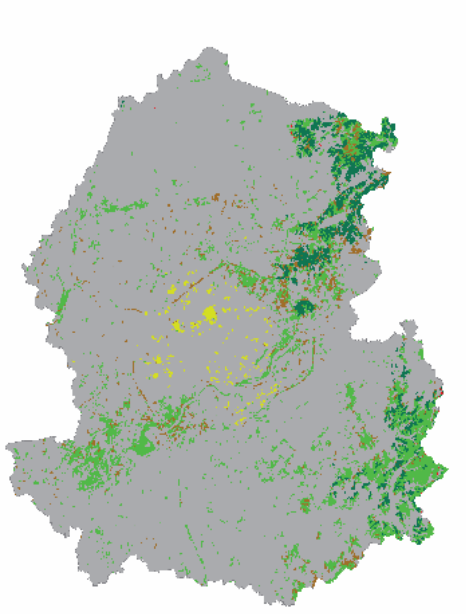

2000

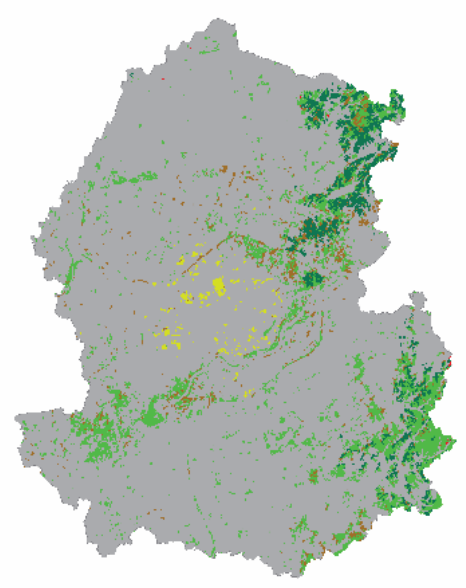

2005
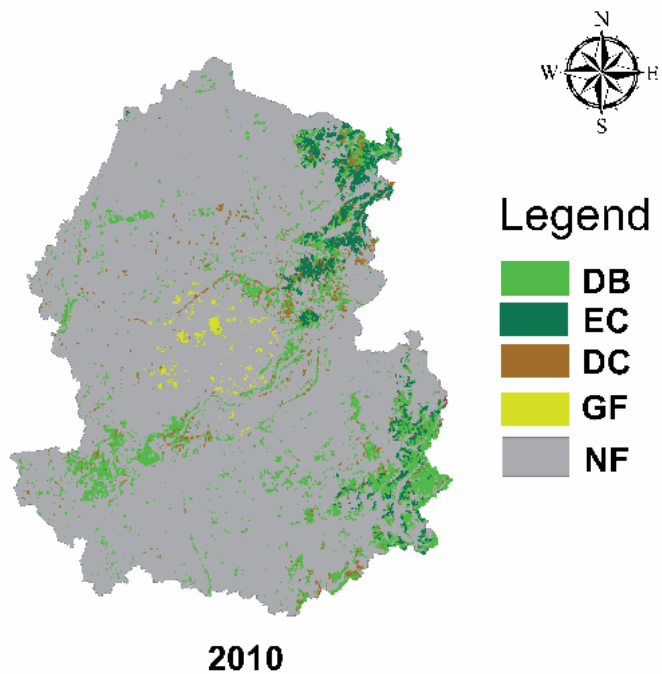

Legend

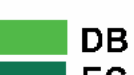

EC

DC

GF

NF

Fig. 2. Spatial extent of different urban forest types in 2000, 2005, and 2010; DB-deciduous broad-leaved forests (DB); EC-evergreen coniferous forests, DC-deciduous coniferous forests, GF-tree green garden forests, NF-non forest zone. 
Table 1. Areas $\left(\mathrm{km}^{2}\right)$ of urban land and different urban forest types in 2000, 2005, and 2010; DB-deciduous broadleaved forests, EC-evergreen coniferous forests, DC-deciduous coniferous forests, and GF-tree green garden forests .

\begin{tabular}{|c|c|c|c|c|c|}
\hline \multirow{2}{*}{ Years } & \multirow{2}{*}{$\begin{array}{c}\text { Urban } \\
\text { land }\end{array}$} & \multicolumn{4}{|c|}{ Urban forest type } \\
\cline { 3 - 6 } & & DB & EC & DC & TGG \\
\hline 2000 & 630.43 & 260.25 & 78.17 & 46 & 16.14 \\
\hline 2005 & 720.47 & 255.32 & 78.05 & 44.39 & 14.7 \\
\hline 2010 & 959.94 & 255.26 & 77.99 & 44.41 & 14.67 \\
\hline
\end{tabular}

classification results. The total accuracy of Shenyang land cover in 2000, 2005, and 2010 were $89.7 \%, 91.3 \%$, and $92.1 \%$, respectively.

The CASA model was used to estimate NPP $\left(\mathrm{g} \mathrm{C} \mathrm{m}^{-2}\right)$, and it was an efficient tool for displaying the spatial and temporal patterns of NPP [24].

We used multi-source remote sensing data of cooperative inversion method to realize the estimation of forest AGB $\left(\mathrm{g} \mathrm{m}^{-2}\right)$. GLAS data were acquired during four different seasons in 2000, 2005, and 2010, respectively. The mean values of AGB of growing season in the three years were considered as the final results. The Specific inversion steps are as follows: (1) based on GLAS data forest canopy height inversion model was developed [23], and we acquired tree height estimation of discrete flare points; (2) based on the inversion results of canopy height, relative growth equation [28] was used to calculate forest AGB of those discrete flare points; and (3) based on seamless inference algorithm, we proceeded with spatial fusion extrapolation of forests AGB. Details of forest canopy height inversion can be found in previous studies [29, 30].

The CASA model input meteorological parameters include average monthly temperatures, precipitations, and monthly total solar radiation in 2000, 2005, and 2010, respectively. The meteorological data were collected from the Northeastern Institute of Weather in
China and were compiled for 1961-2010 from weather stations of and nearby Shenyang city.

Six land covers were acquired after the interpretation of TM images. Then, we divided the forests into four sub-types (Fig. 2) by visual interpretation and field survey methods: deciduous broad-leaved forests (DB), evergreen conifer forests (EC), deciduous conifer forests (DC), and garden forests (GF). Areas of each urban forest type in 2000, 2005, and 2010 are shown in Table 1.

\section{Research Methods}

Shenyang is a city with long history, and it has been the capital of early Qing dynasty when is the origin of the development of Shenyang. The Shenyang imperial palace, which was completed in 1636, served as the center of this city and has been well protected. Therefore, the imperial palace $\left(41^{\circ} 47^{\prime} 49^{\prime \prime} \mathrm{N}, 123^{\circ} 27^{\prime} 20^{\prime \prime} \mathrm{E}\right)$ was selected as Shenyang's urban core.

Beginning with the urban core, we draw buffer rings with every $1 \mathrm{~km}$ width. The total city was divided into 41 buffer rings, and each buffer ring represents a different distance from the urban core. Fig. 1 shows the urban core and buffer rings of Shenyang.

Urban land area percentage (UAP) indicates the proportion of urban land of a particular region, and urban expansion magnitude (UEM) expresses the variation of urban land in unit time. They are vital indicators in reflecting the spatial change of urban expansion. The spatial extents of urban land in 2000, 2005, and 2010 are shown in Fig. 3. We calculated UAP and UEM of different buffer zones and quadrants in Shenyang by the following equation:

$$
\begin{gathered}
U A P_{t, i}=\frac{U A_{t, i}}{A_{i}} \times 100 \% \\
U E M=\frac{U A_{b}-U A_{a}}{A_{i}} \times \frac{1}{T} \times 100 \%
\end{gathered}
$$
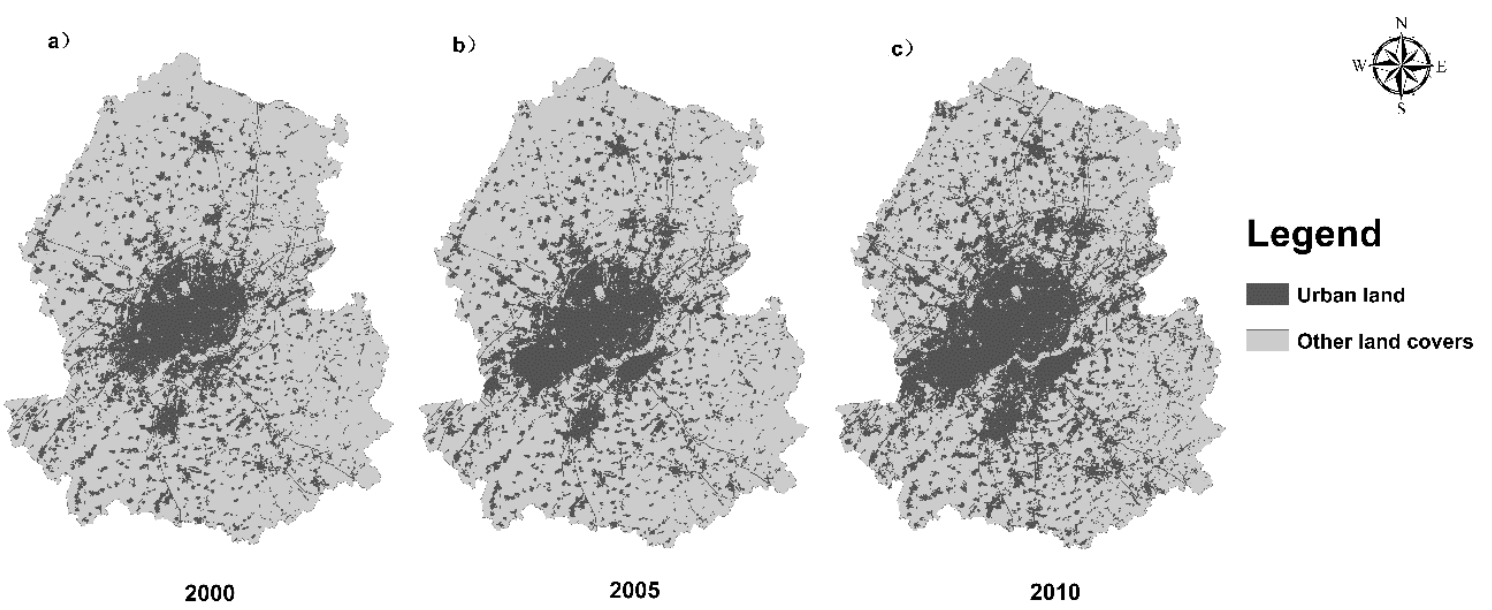

Fig. 3. Spatial extent of Shenyang urban land in 2000, 2005, and 2010. 
...where $U A P_{t, i}(\%)$ is the proportion of urban land of region $i$ at time $t, U A_{t, i}$ is the urban land area of a region $i$ at time $t, A_{i}$ is the area of the region, $\operatorname{UEM}\left(\% \mathrm{a}^{-1}\right)$ is the urban expansion magnitude from time $a$ to time $b, U A_{a}$ is the urban land area $\left(\mathrm{km}^{2}\right)$ at time $a, U A_{b}$ is the urban land area at time $b$, and $T$ is the time interval (a) between time $a$ and time $b$.

In order to be consistent with the urban expansion, we defined $R_{N P P}\left(\mathrm{~g} \mathrm{C} \mathrm{m}^{-2} \mathrm{a}^{-1}\right)$ and $R_{A G B}\left(\mathrm{~g} \mathrm{C} \mathrm{m}^{-2} \mathrm{a}^{-1}\right)$ as the change rate of NPP and AGB over a period of time, respectively. These two indicators reflected carbon sequestration rate of urban forest to some extent, and the following equations were used to compute $R_{N P P}$ and $R_{A G B}$ :

$$
\begin{aligned}
& R_{N P P}=\frac{N P P_{b}-N P P_{a}}{T} \\
& R_{A G B}=\frac{A G B_{b}-A G B_{a}}{T}
\end{aligned}
$$

...where $R_{N P P}$ and $R_{A G B}$ are the change rates of NPP and AGB in the period between time $a$ and time $b . N P P_{b}$, $A G B_{b}, N P P_{a}$, and $A G B_{a}$ are NPP and AGB at time $b$ and time $a . T$ is the time interval (a) between time $a$ and time $b$.

The mean values of NPP and AGB of different forest types represented the carbon sequestration of urban forest. One-way ANOVA was used to test the differences in NPP and AGB among different urban forest types. The significance level of multiple comparisons was set to 0.05 , and the LSD post-hoc test was used, which is suitable for multiple individual $\mathrm{t}$ tests between all pairs of groups. We used Pearson's correlation test to determine whether there were significant correlations between urban expansion indexes (UAP and UEM) and carbon sequestration indexes (NPP, AGB, RNPP, and RAGB). The statistical analyses were conducted using the open resource statistical graphics and computing environment $\mathrm{R}$ [31].

\section{Results}

\section{UAP and UEM}

UAP declined from almost $100 \%$ to 0 (Fig. 4 a) as the distance from urban core of Shenyang increased in the three years $(2000,2005$, and 2010), while a little increase of UAP was detected in the scope of 7-8 km from the city core. The UAP in 2000, 2005, and 2010 increased in turn in the distance range of $6 \mathrm{~km}$ to $35 \mathrm{~km}$ from the urban core; however, there was no obvious difference of UAP in other areas.

Bimodal curves were detected in the change of UEM in the three periods $(2000-2005,2005-2010$, and 2000-2010) as the distance from urban center increased (Fig. 4b). Each period's two peaks of UEM emerged
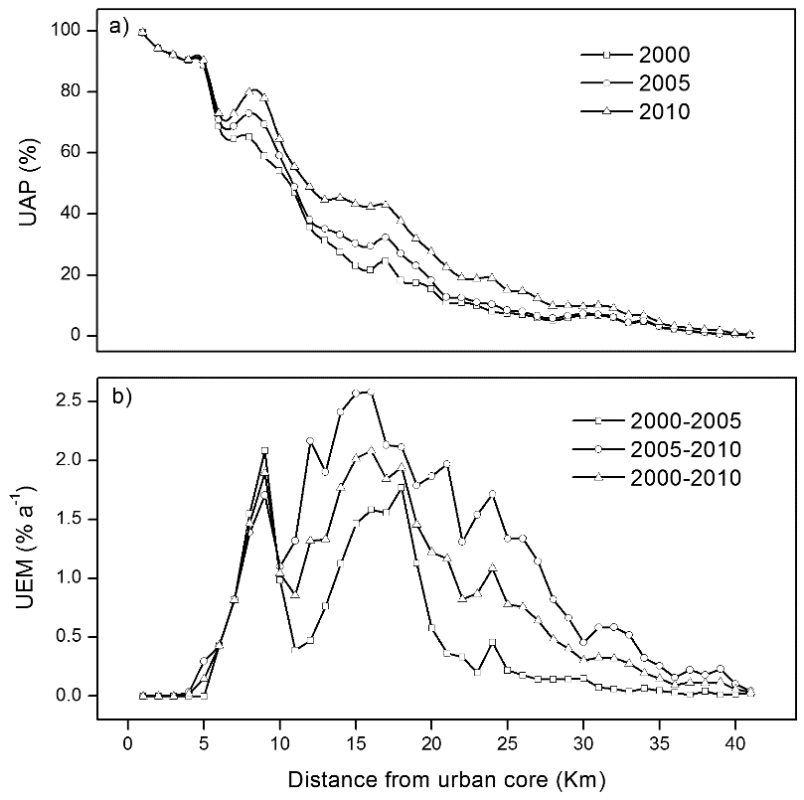

Fig. 4. UAP and UEM dynamics in different regions of Shenyang a) UAP in 2000, 2005, and 2010; b) UEM in 2000-2005, 20052010, and 2000-2010.

around the $9^{\text {th }}$ and $16^{\text {th }}$ buffer rings, respectively. UEM of the three periods were almost the same within $10 \mathrm{~km}$ from the urban center, and all the three periods' UEM equaled 0 when the distance from urban center was less than $4 \mathrm{~km}$. However, UEM in 2005-2010 was clearly higher than that in 2000-2005 and 2000-2010. Since 2005, real estate development accelerated due to the Chinese national sports meeting held in Shenyang, which resulted in the rapid expansion of the urban area.

\section{NPP and AGB of Urban Forest}

Overall rising trends of urban forest NPP in 2000, 2005, and 2010 (Fig. 5a) increased as the distance from the urban center of Shenyang became far, respectively; however, little decline emerged between the $2^{\text {nd }}$ and $3^{\text {rd }}$ buffer rings. There was almost no difference of urban forest NPP in the three years within $20 \mathrm{~km}$ from the urban core. But commonly, NPP of 2000, 2005, and 2010 declined in turn, and they were maintained stably at $3229.93 \mathrm{~g} \mathrm{C} \mathrm{m}^{-2}, 2838.37 \mathrm{~g} \mathrm{C} \mathrm{m}^{-2}$, and $2896.61 \mathrm{~g} \mathrm{C} \mathrm{m}^{-2}$, respectively, when the distance from urban center was larger than $33 \mathrm{~km}$.

Trends of rising along with fluctuations were found in urban forest AGB in 2000, 2005, and 2010 as the distance from the urban center of Shenyang increased (Fig. 5b), and they increased from nearly zero in the urban core to $4465.60 \mathrm{~g} \mathrm{~m}^{-2}, 6425.14 \mathrm{~g} \mathrm{~m}^{-2}$, and $7316.27 \mathrm{~g} \mathrm{~m}^{-2}$, respectively in the urban fringe. Urban forest AGB of the three years within $3 \mathrm{~km}$ from the urban core was kept around zero. The AGB kept increasing in the area of distance to urban core less than 15 and over $33 \mathrm{~km}$ from 2000 to 2010, which indicated that the forest area and quality in this area increased. 

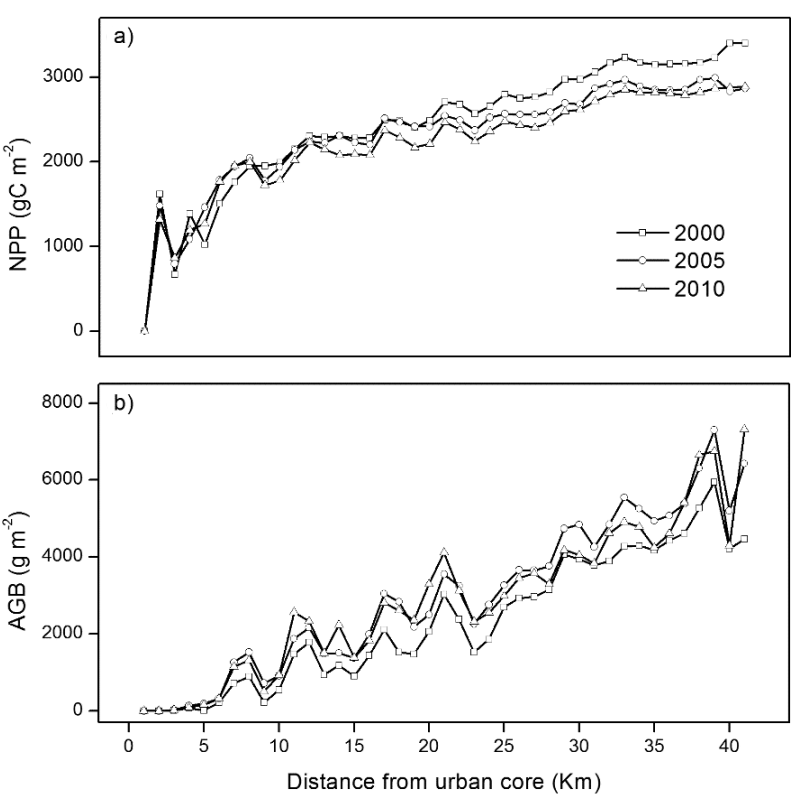

Fig. 5. NPP and AGB dynamics in different regions of Shenyang in 2000, 2005, and 2010; a) NPP; b) AGB.

However, in the area of distance to the urban core from 15 to $33 \mathrm{~km}$, the forest area decreased due to urban area extended. The change of NPP and AGB was mainly caused by urban expansion, which occupied forest land.

\section{RNPP and RAGB of Urban Forest}

Generally, as distance from the urban core increased, $\mathrm{R}_{\mathrm{NPP}}$ in the periods of 2000-2005, 2005-2010, and 2000-2010 fluctuated in the range of $-60 \mathrm{~g} \mathrm{C} \mathrm{m}^{-2} \mathrm{a}^{-1}$ to $10 \mathrm{~g} \mathrm{C} \mathrm{m}^{-2} \mathrm{a}^{-1}$ (Fig. 6a). Most of the
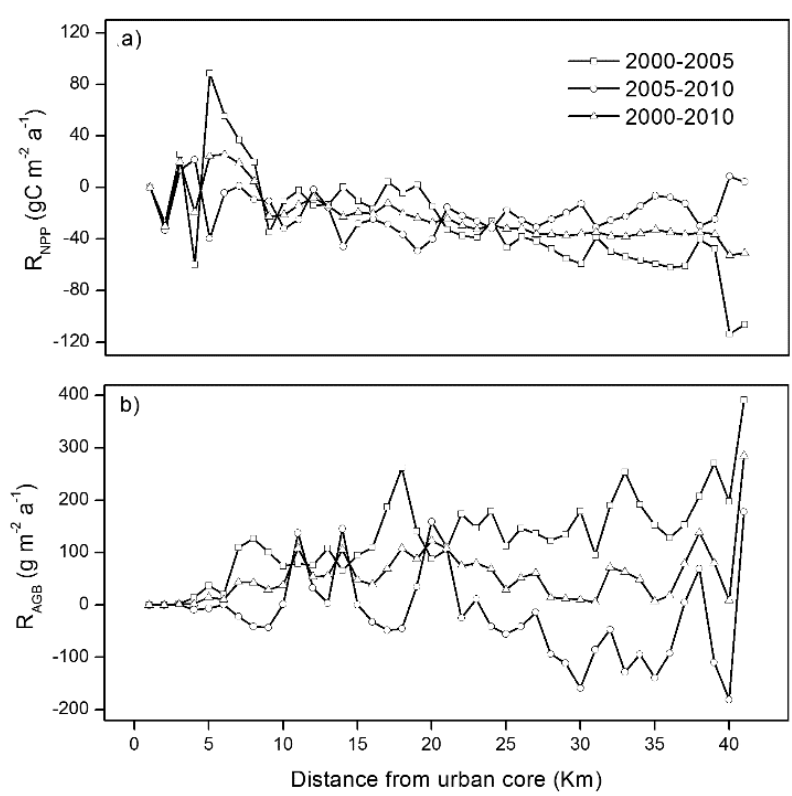

Fig. 6. $\mathrm{R}_{\mathrm{NPP}}$ and $\mathrm{R}_{\mathrm{AGB}}$ dynamics in different regions of Shenyang in 2000-2005, 2005-2010, and 2000-2010; a) NPP; b) AGB.
$\mathrm{R}_{\mathrm{NPP}}$ lower than zero when the distance from urban core lager than $10 \mathrm{~km}$; however, in the period of 2000 to 2005 , $\mathrm{R}_{\mathrm{NPP}}$ had a highest value of 88.42 in the $5^{\text {th }}$ buffer ring and the lowest value of -113.71 in the $40^{\text {th }}$ buffer ring. $\mathrm{R}_{\mathrm{NPP}}$ of 2005-2010 was relatively higher than that of other periods.

$\mathrm{R}_{\mathrm{AGB}}$ of urban forest in the periods of 2000-2005, 2005-2010, and 2000-2010 had rising trends within $20 \mathrm{Km}$ from urban core and then fluctuated drastically, approximately at $201.28 \mathrm{~g} \mathrm{~m}^{-2} \mathrm{a}^{-1},-65.14 \mathrm{~g} \mathrm{~m}^{-2} \mathrm{a}^{-1}$, and $68.07 \mathrm{~g} \mathrm{~m}^{-2} \mathrm{a}^{-1}$, respectively (Fig. 6b). Except in the period of $2005-2010, \mathrm{R}_{\mathrm{AGB}}$ of the other periods commonly larger than zero, and the differences of $\mathrm{R}_{\mathrm{AGB}}$ among the three periods boosted as distance from urban core increased.

\section{Urban Forest Types and their Carbon Sequestration}

There was almost no alterations in the spatial distribution of different urban forest types (Fig. 2). However, significant differences $(P<0.05)$ in NPP and AGB of various urban forest types existed in 2000, 2005, and 2010, respectively. From the multiple comparison results (Table 2) we found that significant differences in NPP and AGB almost existed between any two urban forest types. Commonly, EC had the highest NPP (83.94. $\mathrm{g} \mathrm{m}^{-2}, 73.61 \mathrm{~g} \mathrm{C} \mathrm{m}^{-2}$, and $78.56 \mathrm{~g} \mathrm{C} \mathrm{m}^{-2}$ in 2000, 2005, and 2010, respectively) and AGB (4296.96 $\mathrm{g} \mathrm{m}^{-2}$, $5374.37 \mathrm{~g} \mathrm{~m}^{-2}$, and $4832.10 \mathrm{~g} \mathrm{~m}^{-2}$ in 2000, 2005, and 2010, respectively). However, the minimum NPP (36.56g C m $\mathrm{g}^{-2}, 34.06 \mathrm{~g} \mathrm{C} \mathrm{m}^{-2}$, and $38.62 \mathrm{~g} \mathrm{C} \mathrm{m}^{-2}$ in 2000, 2005, and 2010, respectively) and AGB (504.99 $\mathrm{g} \mathrm{C} \mathrm{m}^{-2}$, $815.60 \mathrm{~g} \mathrm{C} \mathrm{m}^{-2}$, and $684.27 \mathrm{~g} \mathrm{C} \mathrm{m}^{-2}$ in 2000,2005 , and 2010, respectively) existed in GF. The values of SD of AGB means the change of biomass in spatial distribution and DC had the greatest SD values. However, GF has the lowest values due to more anthropic management. The same meanings to the values of SD of NPP, however, the situation was different between AGB and NPP. NPP of EC had the lowest value of SD, which indicated that the ability of NPP was the most even distribution. As to the same urban forest type, NPP declined from 2000 to 2005 while rising from 2005 to 2010. However, urban forest AGB showed disparate change with time. AGB sharply increased from 2000 to 2005 while a slight decline emerged from 2005 to 2010.

\section{Impact of Urban Expansion on Carbon Sequestration}

In total, UAP was linearly correlated with NPP (Fig. 7a) and logarithmically correlated with AGB (Fig. 7b). They were both negative correlations but had high correlation coefficients $\left(\mathrm{R}^{2}=0.85\right.$ and 0.77$)$. NPP in different years was significantly $(P<0.01)$ linearly correlated with UAP (Table 3 ). UAP explained approximately $88 \%, 85 \%$, and $84 \%$ of the variance in urban forest NPP in 2000, 2005, and 2010, respectively. 
Table 2. NPP $\left(\mathrm{g} \mathrm{C} \mathrm{m}^{-2}\right)$ and AGB $\left(\mathrm{g} \mathrm{m}^{-2}\right)$ of different urban forest types in 2000, 2005, and 2010; values are in the form of mean $\pm \mathrm{SD}$, with each patch of urban forest regarded as a sample, and the sample size $n>30$; different lowercase letters after the values mean significant differences of NPP and AGB in different urban forest types $(\mathrm{P}<0.05)$.

\begin{tabular}{|c|c|c|c|c|}
\hline Variables & DB & $\mathrm{EC}$ & DC & GF \\
\hline \multicolumn{5}{|c|}{2000} \\
\hline NPP & $65.21 \pm 15.44 \mathbf{b}$ & $83.94 \pm 9.86 \mathbf{c}$ & $69.89 \pm 13.12 \mathbf{b}$ & $36.56 \pm 15.39 \mathbf{a}$ \\
\hline AGB & $2775.01 \pm 739.27 \mathbf{c}$ & $4296.96 \pm 987.76 d$ & $1828.82 \pm 1102.50 \mathbf{b c}$ & $504.99 \pm 384.87 \mathbf{a}$ \\
\hline \multicolumn{5}{|c|}{2005} \\
\hline NPP & $57.53 \pm 14.18 \mathbf{b}$ & $73.61 \pm 11.23 d$ & $62.49 \pm 13.25 \mathrm{c}$ & $34.06 \pm 14.85 \mathbf{a}$ \\
\hline AGB & $3447.41 \pm 884.21 \mathbf{c}$ & $5374.37 \pm 754.36 \mathbf{d}$ & $2524.08 \pm 1020.12 \mathbf{b}$ & $815.60 \pm 298.79 \mathbf{a}$ \\
\hline \multicolumn{5}{|c|}{2010} \\
\hline NPP & $61.52 \pm 10.21 \mathbf{b}$ & $78.56 \pm 7.51 \mathbf{c}$ & $64.11 \pm 12.05 \mathbf{b}$ & $38.62 \pm 12.45 \mathbf{a}$ \\
\hline AGB & $3346.22 \pm 775.54 c$ & $4832.10 \pm 986.48 \mathbf{d}$ & $2433.64 \pm 987.25 \mathbf{b c}$ & $684.27 \pm 298.57 \mathbf{a}$ \\
\hline
\end{tabular}

Logarithmic correlations $(P<0.01)$ were identified between UAP and AGB in 2000, 2005, and 2010 (Table 3). UAP explained approximately $89 \%, 91 \%$, and $87 \%$ of the variance in urban forest AGB of different distances from the urban center in the three years.

No obvious correlation could be found between UEM and $\mathrm{R}_{\mathrm{NPP}}$ (Fig. 7c), while $\mathrm{R}_{\mathrm{AGB}}$ had a first decline and then rising trend as UEM increased (Fig. 7d) in general. However, significant $(P<0.05)$ correlation between UEM and $\mathrm{R}_{\mathrm{NPP}}$ was found in the periods of 2000-2005 and 2005-2010 (Table 3), but this correlation did not exist in 2000-2010. Significant correlation $(P<0.05)$ between UEM and $\mathrm{R}_{\mathrm{AGB}}$ was only found in the period of 2005-2010, and the correlation coefficient was relative small $\left(\mathrm{R}^{2}=0.32\right)$.

\section{Discussion}

\section{Urban Expansion of Different Distances from the Urban Core}

As the distance from Shenyang center increases, UAP in 2000, 2005, and 2010 generally decreased from $100 \%$ in the urban core area to zero in the urban margin. This is similar to some other studies that have focused on urban expansion and its environmental effects [32, 33]. The decline of UAP is because that region near the urban core is mainly construction and roads that are one of the commercial centers. Other land covers such as grass and forests emerge as distance from the urban core becomes far. However, an abnormal rise of UAP in 2005 and 2010 was found between the 6th and 8th buffer rings. It is likely that ecological land was added in those areas with urban development.

Higher UEM in the period of 2000-2005 emerged in the place approximately $8 \mathrm{~km}$ from urban core; however, the peak value of UEM in 2005-2010 emerged at the place $16 \mathrm{~km}$ away from the urban core. This corresponded with some parallel research [34]. The area within $8 \mathrm{~km}$ of the urban center is the old town, and early urban expansion mainly occurred in this area; however, this expansion was restrained due to limited space. The region outside the old town has enough space and resources, and it supplied well conditions for urban expansion. Consequently, a large increase of UEM in 2005-2010 was identified there.

\section{Urban Forest Carbon Sequestration}

Our results showed trends of rising with fluctuations in urban forest NPP and AGB when the distance from

Table 3. $\mathrm{R}^{2}$ values of Pearson's correlations between urban land area percentage (UAP) and NPP and AGB of 2000, 2005, and 2010, respectively, as well as urban expansion magnitude (UEM) and change rate of $\mathrm{NPP}\left(\mathrm{R}_{\mathrm{NPP}}\right)$ and $\mathrm{AGB}\left(\mathrm{R}_{\mathrm{AGB}}\right)$ of 2000-2005, 2005-2010, and 2000-2010, respectively; $\mathrm{R}$ square with “*” indicates the correlation is significant $(\mathrm{P}<0.05)$, $\mathrm{R}$ square with "***" indicates the correlation is strongly significant $(\mathrm{P}<0.01)$.

\begin{tabular}{|c|c|c|c|c|c|c|}
\hline \multirow{2}{*}{ Variables } & \multicolumn{3}{|c|}{ UAP } & \multicolumn{3}{c|}{ UEM } \\
\cline { 2 - 7 } & 2000 & 2005 & 2010 & $2000-2005$ & $2005-2010$ & $2000-2010$ \\
\hline $\mathrm{NPP}$ & $0.88^{* *}$ & $0.85^{* *}$ & $0.84^{* *}$ & - & - & - \\
\hline $\mathrm{AGB}$ & $0.69^{* *}$ & $0.76^{* *}$ & $0.81^{* *}$ & - & - & - \\
\hline $\mathrm{R}_{\mathrm{NPP}}$ & - & - & - & $0.37^{*}$ & $0.47^{*}$ & 0.17 \\
\hline $\mathrm{R}_{\mathrm{AGB}}$ & - & - & - & 0.03 & $0.32^{*}$ & 0.17 \\
\hline
\end{tabular}



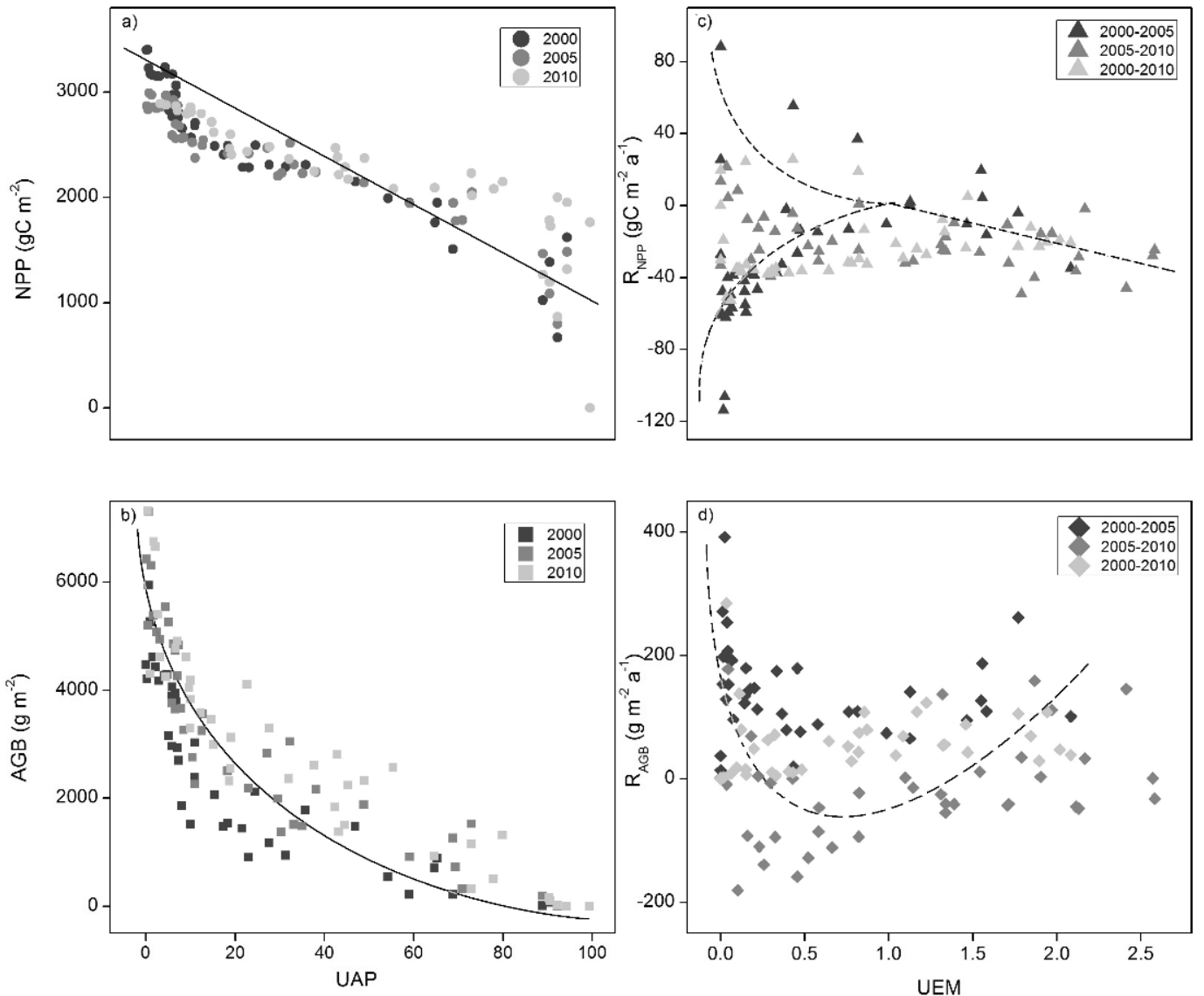

Fig. 7. Distributions of carbon sequestration indexes (NPP and AGB) with urban expansion indexes (UAP and UEM); the solid line shows the correlations between variables and the dashed line shows the dynamic trend of variables; a) NPP distribution with UAP, the fit equation is $\mathrm{y}=-19.645 \mathrm{x}+2942.2\left(\mathrm{R}^{2}=0.85\right)$; b) AGB distribution with UAP, the fit equation is $\mathrm{y}=-1075 * \ln (\mathrm{x})+5593.8\left(\mathrm{R}^{2}=0.77\right)$; c) $\mathrm{R}_{\mathrm{NPP}}$ distribution with UEM; d) $\mathrm{R}_{\mathrm{AGB}}$ distribution with UEM.

the urban center increased; however, the fluctuation of AGB was more drastic. The main reason is that NPP reflects the process of carbon accumulation and was mainly affected by meteorology and the physiology of vegetation, while AGB represents the consequence of carbon sequestration and was influenced by more external factors. Because of less human activities, growth conditions such as solar, water, and soil nutrition far away from the urban center was generally better than that near the urban core. The productivity of urban forests then got promoted, and finally biomass accumulation increased [35].

RNPP reflects the alteration of an urban forest's ability for carbon sequestration, while RAGB represents the carbon sequestration rate of urban forest. When the distance from the urban core exceeds $8 \mathrm{~km}$, RNPP was generally below zero in all periods. This indicates that the ability of urban forest carbon sequestration was damaged in the process of urban expansion. However, in the city center, an urban forest's carbon sequestration ability was enhanced, which may be due to good protection. Nonetheless, RAGB in the period of 2005-2010 declined below zero, especially in the place with the distance from urban core further than
$15 \mathrm{~km}$, which means that carbon storage in urban forest had decreased. It may be because the urban area had expanded further (Fig. 6) in the period of 2005-2010, and this expansion would certainly bring more disturbances to the urban forest. Moreover, compared to the nature temperate forest's carbon sequestration rate, which commonly fluctuates in the range between $-10 \mathrm{tha}^{-1}$ to $10 \mathrm{t} \mathrm{ha}^{-1}$, RAGB of urban forest is relatively smaller. This demonstrates that the urban forest experiences more control by human activities.

Both significant $(\mathrm{P}<0.05)$ differences in NPP and AGB were found among the four urban forest types. EC commonly had the highest values of NPP while their minimum values were detected in GF. This indicated that the ability of energy transformation from solar radiation of EC was higher. Moreover, urban forest $\mathrm{AGB}$ in $\mathrm{EC}$ and $\mathrm{DB}$ was greater than that of other forest types. This gives us important implications on urban forest management. Broadleaved tree species are usually selected to afforest in urban areas due to the consideration of survival probability and expense [11]; however, evergreen conifers have a higher ability for carbon sequestration. Therefore, evergreen coniferous forests are worth considering in future urban forest 
planning. The mean urban forest $\mathrm{AGB}$ in the last ten years was $27.59 \mathrm{t} \mathrm{ha}^{-2}$, and it is far below the AGB of nature forest in northeast China, which was reported to be higher than $100 \mathrm{t} \mathrm{ha}^{-2}$. This demonstrates that great potential of carbon storage exists in the urban forest, and urban forests may play an important role in climate warming mitigation.

\section{Impacts of Urban Expansion on Urban Forest Carbon Sequestration}

Complex interactions of climate change, land use change, hydrology process, and disturbances aroused by humans and nature have greatly influenced the global carbon cycle [6]. Urban expansion is a vital driving factor for increasing greenhouse gas emissions by damaging the productivity of urban forests [36]. However, studies of carbon sequestration of terrestrial ecosystems have often ignored the vegetation in urban areas. In this study, we have found that urban expansion largely controlled the carbon sequestration in urban forests. NPP was significant $(\mathrm{P}<0.01)$ linear negatively correlated with UAP in 2000, 2005, and 2010. UAP explained more than $80 \%$ in different buffer rings. Significant $(\mathrm{P}<0.01)$ negative logarithmic correlations existed between AGB and UAP in 2000, 2005, and 2010. The main reason is that microclimate conditions such as temperature and solar radiation are affected by more established tall buildings as the increasing of UAP, which will certainly decrease the productivity of urban forests [37]. Furthermore, the regions with lower UAP offer more space for the growth of urban forests, and urban forests in Shenyang are mainly distributed in suburbs and exurbs where UAPs are relative lower. As a result, urban forest AGB rose with the decline of UAP.

UEM reflects the variation of urban expansion in unit time, and it may affect the change rate of NPP and AGB of urban forest. Our results reported that significant $(\mathrm{P}<0.05)$ linear positive correlations were found between RNPP and UEM in 2000-2005 and 2005-2010, and the correlation coefficients were 0.37 and 0.47 , respectively. Significant $(\mathrm{P}<0.05)$ linear positive correlation between RAGB and UEM was only identified in the period of 2005-2010. This suggests that the change rate of carbon sequestration process is not simply affected by UEM. Though UEM quantifies urban expansion, it cannot display the original state of urban ecosystems and the details about urban expansion processes. Lower UEM generally emerges in the place near urban core or in the urban fringe area. If we divided these two areas, RNPP increased as the distance from urban core increased; however, RNPP decreased as distance from the urban core decreased (Fig. 7c). This suggests that urban forests in the exurbs are likely to be similar with natural forest, and their responses to urban expansion are insensitive.

Nonetheless, trends of rising after a decline were found in RAGB with the increase of UEM, and the inflection point commonly appeared at UEM equal to $0.5 \%$ a-1 (Fig. $7 d$ ). This indicates that different UEM represents various urban expansion types [26], and different urban expansion types might cause different effects on urban forest carbon sequestration. Commonly, a region with UEM less than 0.5 is mainly used to construct industrial projects, which will bring harm to urban forest and neglect the restoration of damaged forests. However, regions with high UEM commonly have perfect planning and protections of urban forest. These areas are mainly used to construct infrastructure related to human lives. Under the guideline of sustainable development, urban forests generally obtain good protection.

\section{Ecological Insight and Implications}

Though some previous studies have explored the relationships between urbanization and carbon sequestration [11, 38], most of them have regarded different administrative districts as different urbanization levels. In this study, we determined the urban center, and several buffer rings were divided based on the center point. This made it easy to quantify urban expansion in different distances from the urban core of this city. Therefore, relationships between urban expansion and urban forest carbon sequestration can be explained more profoundly.

Furthermore, NPP and AGB are important indexes in estimating urban forest carbon sequestration. Exploring the dynamics of these two indicators under urban expansion at the same time can understand the processes and results of urban forest carbon sequestration, and many useful implications for urban forest management are obtained.

Based on multiple remote sensing data, we realized the studying of temporal and spatial dynamics of urban forest; however, some disadvantages were accompanied with the methods. On the one hand, the estimations of NPP and AGB were lower than true values because remote sensing could not supply details of the understory of urban forest. On the other hand, due to the inconstant conditions of meteorology, systematic errors existed among remote sensing data of different times.

Carbon sequestration of urban forest is certainly influenced by many other factors [39] such as population, economic development, climate, and soil, etc. Only after entirely analyzing these factors and their interactions can we accurately evaluate carbon sequestration. Moreover, three-dimensional urban expansion brings more complex ecological and environmental effects in urban areas [40-42]. In future, multi-factors and multiscales should be taken into account in studying urban expansion and its ecological effects.

\section{Conclusions}

This study investigates the impacts of urban expansion on carbon sequestration of urban forest in Shenyang, China. We conclude that urban expansion 
focuses on different areas of the city in various stages of development, and the direction of urban expansion is generally toward suburban areas. Compared to natural forests, urban forests obtain more disturbances, and urban expansion in Shenyang controls the distribution of urban forest NPP and AGB. Moreover, the evergreen coniferous forest has the highest ability of carbon sequestration, and great potential of carbon storage is found in urban forests. Besides, different types of urban expansion bring various influences on urban expansion, and the urban forest's carbon sequestration function will be maintained when adopting the appropriate urban development mode.

\section{Acknowledgments}

This project was supported by the China National 'Ecological Risk Management and Spatial Pattern Optimization in Urban Areas' R\&D Program (No. 2017YFC0505704) and the National Natural Science Foundation of China (Nos. 41671184, 41671185 and 41401573).

\section{Conflict of Interest}

All authors declare no conflict of interest.

\section{References}

1. YAN D., SCHNEIDER U. A., SCHMID E., HUANG H. Q., PAN L. H., DILLY O. Interactions between land use change, regional development, and climate change in the Poyang Lake district from 1985 to 2035. Agricultural Systems. 119, 10, 2013.

2. FOLEY J.A., DEFRIES R., ASNER G.P., BARFORD C., BONAN G., CARPENTER S.R., CHAPIN F.S., COE M.T., DAILY G.C., GIBBS H.K., HELKOWSKI J.H., HOLLOWAY T., HOWARD E.A., KUCHARIK C.J., MONFREDA C., PATZ J.A., PRENTICE I.C., RAMANKUTTY N., SNYDER P.K. Global consequences of land use. Science. 309 (5734), 570, 2005.

3. VAN ASSELEN S., VERBURG P.H. Land cover change or land-use intensification: simulating land system change with a global-scale land change model. Global Change Biology. 19 (12), 3648, 2013.

4. SCHNEIDER A., LOGAN K.E., KUCHARIK C.J. Impacts of Urbanization on Ecosystem Goods and Services in the U.S. Corn Belt. Ecosystems. 15 (4), 519, 2012.

5. DECKER E.H., ELLIOTT S., SMITH F.A., BLAKE D.R., ROWLAND F.S. Energy and material flow through the urban ecosystem. Annual Review of Energy and the Environment. 25, 685, 2000.

6. HUTYRA L.R., YOON B., ALBERTI M. Terrestrial carbon stocks across a gradient of urbanization: a study of the Seattle, WA region. Global Change Biology. 17 (2), 783, 2011.

7. ZHOU Y., SMITH S.J., ZHAO K., IMHOFF M., THOMSON A., BONDLAMBERTY B., ASRAR G.R.,
ZHANG X., HE C., Elvidge C.D. A global map of urban extent from nightlights. Environmental Research Letters. 10 (5), 2015.

8. PENG J., TIAN L., LIU Y., ZHAO M., HU YN., WU J. Ecosystem services response to urbanization in metropolitan areas: Thresholds identification. Science of The Total Environment. 607, 706, 2017.

9. SMORKALOV I.A., VOROBEICHIK E.L. The impact of a large industrial city on the soil respiration in forest ecosystems. Eurasian Soil Science. 48 (1), 106, 2015.

10. PENG J., MA J., LIU Q., LIU Y., HU Y., LI Y., YUE Y. Spatial-temporal change of land surface temperature across 285 cities in China: An urban-rural contrast perspective. Science of The Total Environment. 635, 487, 2018.

11. REN Y., WEI X., WEI X., PAN J., XIE P., SONG X., PENG D., ZHAO J. Relationship between vegetation carbon storage and urbanization: A case study of Xiamen, China. Forest Ecology and Management. 261 (7), 1214, 2011.

12. BEYENE A.D., KOCH S.F. Clean fuel-saving technology adoption in urban Ethiopia. Energy Economics. 36, 605, 2013.

13. MONDAL P., BUTLER B.J., KITTREDGE D.B., MOSER W.K. How are America's private forests changing? An integrated assessment of forest management, housing pressure, and urban development in alternate emissions scenarios. Land Use Policy. 32, 230, 2013.

14. WHITE R.H., ZIPPERER W.C. Testing and classification of individual plants for fire behaviour: plant selection for the wildland-urban interface. International Journal of Wildland Fire. 19 (2), 213, 2010.

15. EHRENFELD J.G. The expression of multiple functions in urban forested wetlands. Wetlands. 24 (4), 719, 2004.

16. REN Y., DENG L., ZUO S., LUO Y., SHAO G., WEI X., HUA L., YANG Y. Geographical modeling of spatial interaction between human activity and forest connectivity in an urban landscape of southeast China. Landscape Ecology. 29 (10), 1741, 2014.

17. BUFFAM I., TURNER M.G., DESAI A.R., HANSON P.C., $\dagger$ J.A.R., LOTTIG N.R., STANLEY E.H., CARPENTER S.R. Integrating aquatic and terrestrial components to construct a complete carbon budget for a north temperate lake district. Global Change Biology. 17 (2), 1193, 2011.

18. WU J., BAUER M.E. Estimating Net Primary Production of Turfgrass in an Urban-Suburban Landscape with QuickBird Imagery. Remote Sensing. 4 (4), 849, 2012.

19. PIMM S.L., RAVEN P. Biodiversity - Extinction by numbers. Nature. 403 (6772), 843, 2000.

20. SALA O.E., CHAPIN F.S., ARMESTO J.J., BERLOW E., BLOOMFIELD J., DIRZO R., HUBER-SANWALD E., HUENNEKE L.F., JACKSON R.B., KINZIG A., LEEMANS R., LODGE D.M., MOONEY H.A., OESTERHELD M., POFF N.L., SYKES M.T., WALKER B.H., WALKER M., WALL D.H. Biodiversity - Global biodiversity scenarios for the year 2100. Science. 287 (5459), 1770, 2000

21. HOUGHTON R.A., HACKLER J.L., LAWRENCE K.T. The US carbon budget: Contributions from land-use change. Science. 285 (5427), 574, 1999.

22. VANEK S.J., DRINKWATER L.E. Environmental, Social, and Management Drivers of Soil Nutrient Mass Balances in an Extensive Andean Cropping System. Ecosystems. 16 (8), 1517, 2013

23. XING Y.Q., DE GIER A., ZHANG J.J., WANG L.H. An improved method for estimating forest canopy height using ICESat-GLAS full waveform data over sloping terrain: A 
case study in Changbai mountains, China. International Journal of Applied Earth Observation and Geoinformation. 12 (5), 385, 2010.

24. POTTER C.S., RANDERSON J.T., FIELD C.B., MATSON P.A., VITOUSEK P.M., MOONEY H.A., KLOOSTER S.A. Terrestrial ecosystem production - a process model-based on global satellite and surface data. Global Biogeochemical Cycles. 7 (4), 811, 1993.

25. FORRESTER J.A., MLADENOFF D.J., GOWER S.T. Experimental Manipulation of Forest Structure: Near-Term Effects on Gap and Stand Scale C Dynamics. Ecosystems. 16 (8), 1455, 2013.

26. LIU C.F., LI X.M. Carbon storage and sequestration by urban forests in Shenyang, China. Urban Forestry \& Urban Greening. 11 (2), 121, 2012.

27. LEWIS D.B., FEIT S.J. Connecting carbon and nitrogen storage in rural wetland soil to groundwater abstraction for urban water supply. Global Change Biology. 21 (4), 1704, 2015.

28. FAYAD I., BAGHDADI N., BAILLY J.S., BARBIER N. Regional scale rain-forest height mapping using regression-kriging of spaceborne and airborne LiDAR data: Application on French Guiana. In: Geoscience and Remote Sensi ng Symposium. 4109, 2016.

29. HILBERT C., SCHMULLIUS C. Influence of Surface Topography on ICESat/GLAS Forest Height Estimation and Waveform Shape. Remote Sensing. 4 (8), 2210, 2012.

30. HAYASHI M., SAIGUSA N., OGUMA H., YAMAGATA Y. Forest canopy height estimation using ICESat/GLAS data and error factor analysis in Hokkaido, Japan. Isprs Journal of Photogrammetry \& Remote Sensing. 81 (7), 12, 2013.

31. R Development Core Team. R: A Language and Environment for Statistical Computing. In: $R$ Foundation for Statistical Computing. pp. Vienna, 2011.

32. SUN Y., LIU Z.Q., WANG Q.B., LIU H.B. SpatialExpansion of Urban LandUse and Its Driving Forces in ShenyangCityover the Past Century. Resources Science. 33 (11), 2022, 2011.

33. ZHANG Y.J., YU G.R., YANG J., WIMBERLY M.C., ZHANG X.Z., TAO J., JIANG Y.B., ZHU J.T. Climate- driven global changes in carbon use efficiency. Global Ecology and Biogeography. 23 (2), 144, 2014.

34. THEOBALD D.M., ROMME W.H. Expansion of the US wildland-urban interface. Landscape and Urban Planning. 83 (4), 340, 2007.

35. VACKAR D., ORLITOVA E. Human appropriation of aboveground photosynthetic production in the Czech Republic. Regional Environmental Change. 11 (3), 519, 2011.

36. BARÓ F., HAASE D., GÓMEZ-BAGGETHUN E., FRANTZESKAKI N. Mismatches between ecosystem services supply and demand in urban areas: A quantitative assessment in five European cities. Ecological Indicators. 55, 146, 2015.

37. CAI W.H., YANG J., LIU Z.H., HU Y.M., WEISBERG P.J. Post-fire tree recruitment of a boreal larch forest in Northeast China. Forest Ecology and Management. 307, 20, 2013.

38. LI C., LI J., WU J. Quantifying the speed, growth modes, and landscape pattern changes of urbanization: a hierarchical patch dynamics approach. Landscape Ecology. 28 (10), 1875, 2013.

39. CHEN T., HUANG Q.H., LIU M., LI M.C., QU L., DENG S.L., CHEN D. Decreasing Net Primary Productivity in Response to Urbanization in Liaoning Province, China. Sustainability. 9 (2), 2017.

40. LUO X., HE H.S., LIANG Y., WANG W.J., WU Z., FRASER J.S. Spatial simulation of the effect of fire and harvest on aboveground tree biomass in boreal forests of Northeast China. Landscape Ecology. 29 (7), 1187, 2014.

41. CHOW W.T.L., POPE R.L., MARTIN C.A., BRAZEL A.J. Observing and modeling the nocturnal park cool island of an arid city: horizontal and vertical impacts. Theoretical and Applied Climatology. 103 (1-2), 197, 2011.

42. SHI L., SHAO G., CUI S., LI X., LIN T., YIN K., ZHAO J. Urban three-dimensional expansion and its driving forces - A case study of Shanghai, China. Chinese Geographical Science. 19 (4), 291, 2009.

43. LIU M., XU Y., HU Y., LI C., SUN F., CHEN T. A century of the evolution of the urban area in Shenyang, China. Plos One. 9 (6), 98847, 2014. 
